\title{
Predisposing Factors for Murosere
}

\author{
Deependra Kumar Anand and Anil K Dwivedi* \\ Department of Botany, DDU Gorakhpur University, India
}

Submission: January 25, 2017; Published: February 09, 2017

*Corresponding author: Anil K Dwivedi, Department of Botany, Pollution \& Environmental Assay Research Laboratory (PEARL), DDU

Gorakhpur University, Gorakhpur 273009, UP, India, Email:anil.k.dwiwedi@gmail.com

\begin{abstract}
Murophytes is a novel hybrid term, the original terms "mural" stands for wall and the term "phytes" stands for the plants of the flora. Therefore, the term murophytes means the plants growing over the walls or buildings. The term Murosere stands for the development of different stages of plants growing over the buildings. The paper deals with the study of site and colonization mode of plants on the wall of historical buildings, monuments, houses, civil engineering structure and drainage pipes etc. The biophysical weathering of building as well as that of many monuments is a problem identified since antiquity. The study deal with the various species of genus Ficus found growing over the buildings and playing very dominant role in damaging the buildings. The three Ficus species, Ficusreligiosa, Ficusbenghalensis and Ficusglomerata are mostly growing over the buildings. These three Ficus species are mostly responsible for uprooting of plasters, widening of gap or cracks and crevices and deterioration of upper surface of building and causing considerable and visible damage of the buildings. Seeds of Ficus species are produced by method of dispersal or by physical and biological agents. In the present paper the Ficus species with reference to some preventive action to controls the damage of heritage buildings has been discussed.
\end{abstract}

Keywords: Murophyte; Murosere; Monuments; Ficus; Plants

\section{Introduction}

Architecture can be described as the sum of the social economic political and cultural developments. The places people live in also live for years. The representative of architectural heritage each has its own architectural historical and cultural message have undertaken a social duty to give cultural message to their environment and future generation. Architecture taking place at the intersection zone of technique and art is the physical and permanent sign of social and economic life cultural and national structural cultural [1]. The historical monuments sustained from past to present have worn out to various effects and disappeared in short periods due to lack of care. The deteriorations on the construction materials have occurred not only because of the year but also mostly due to the environment and the other is material of construction. The buildings are unfavorably affected from changing natural environment and climate conditions [2]. Climate can be defined as the whole atmospheric events such as rain fall, temperature, wind, pressure and humidity that cause certain damages on the monumental buildings for years.

Plant can live in aquatic, terrestrial and organic environments. Their growth influenced by many parameters. There are habitats in which the extreme condition leads to the selection of species with morphological and physiological adaptation enabling them to survive. Walls constitute a specialized microhabitat; since they are built by man, they are restricted to inhibited areas. Murophytes developed in historical periods in which civilized man constructed buildings .The oldest wall or those most characteristically covered in vegetation. In general it is possible to distinguish stone which is an integral part of inhibited building, stonework on the ground (part of old fortifications, roads, etc.) and isolated walls The term Murosere stands for the development of different stages of plants growing over the buildings. The best habitats are provided by retaining walls; through the cracks the earth supplies moisture, particles of soil and nutrients. Hence the factors promoting the colonization of a wall by murophytes are its edaphic preferences, the quantity of seeds produced and the method of dispersal [3].

The following predominating factors are responsible for growth and developments of murophytes:

i. Availability of water

ii. Exposure

iii. Light

iv. Substrate

v. Nutrients

vi. Shady place 
vii. Birds excitements

viii. Type of building structure

\section{Edaphic Preferences}

Specie and environment dependent:

A. Volume of substrate available

B. Type of substrate

C. Exposure

D. Moisture requirements for germination and reproduction

Dispersal Methods

In order of decreasing advantage:

A. Anemochory due to lightness of seeds

B. Anemochory due to special structures (pappi, wings, etc.)

C. Myrmecochory

D. Zoochory

E. Other dispersal mechanism (Figure 1 \& 2)

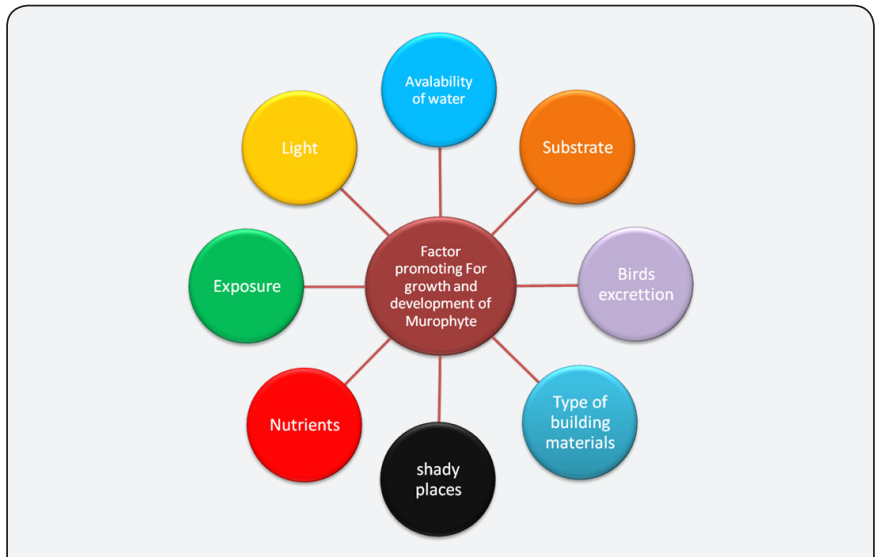

Figure 1: The most predominating factors responsible for growth and development of murophytes.

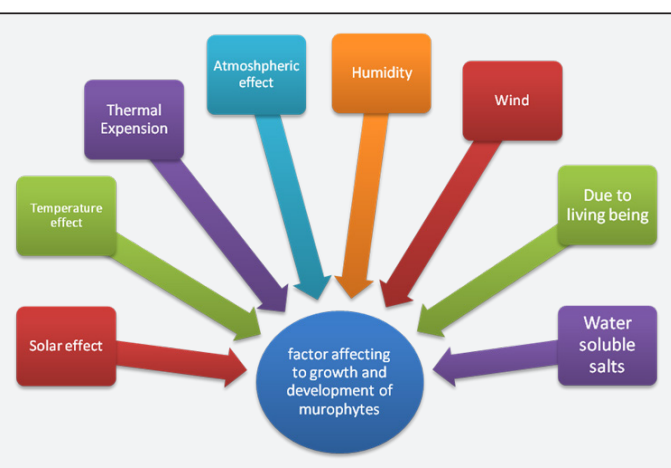

Figure 2: Some other factors for germination and growth of murophytes.

\section{Water}

Water is an impartment factor to growth and development of murophyte. Naturally the availability of water varies with the type of surface and its exposure. It is one of the essential conditions for the establishment and maintenance of vegetation (Figure 3).

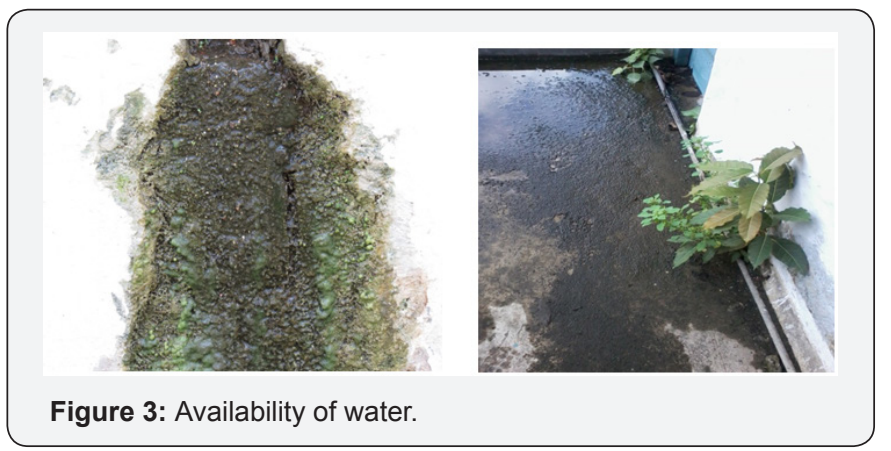

\section{Exposure}

The exposure of the wall is important above all in relation to the main direction of the rain. Arid wall exposed to the sun for many hours of the day determine strict selection of the murophytes. Southern exposures absorb more solar radiation than northern exposures. In mountain communities, northern exposures will have shorter growing seasons [4]. In mountain communities gardeners often place warm season plants, like tomatoes, on the south side of buildings to capture more heat (Figure 4).

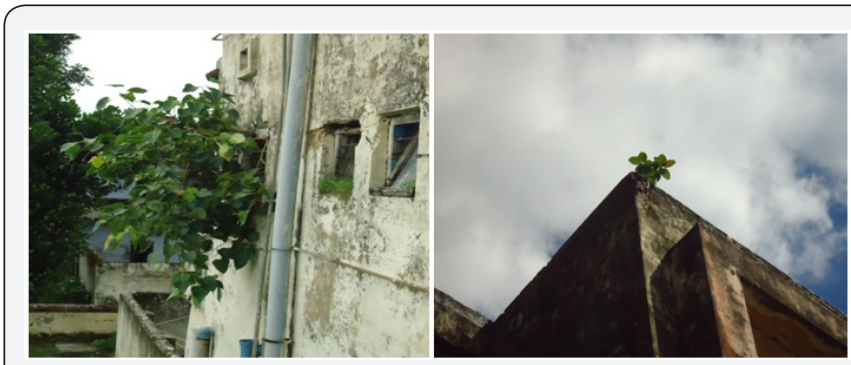

Figure 4: Exposure of the wall.

\section{Light}

Light is the essential for photosynthesis a process by which plants manufacturer their food. Therefore the quality duration and intensity of light available to the plants is of most important in their growth on monuments or buildings. The growth of murophytes is limited in condition of low light (Figure 5).

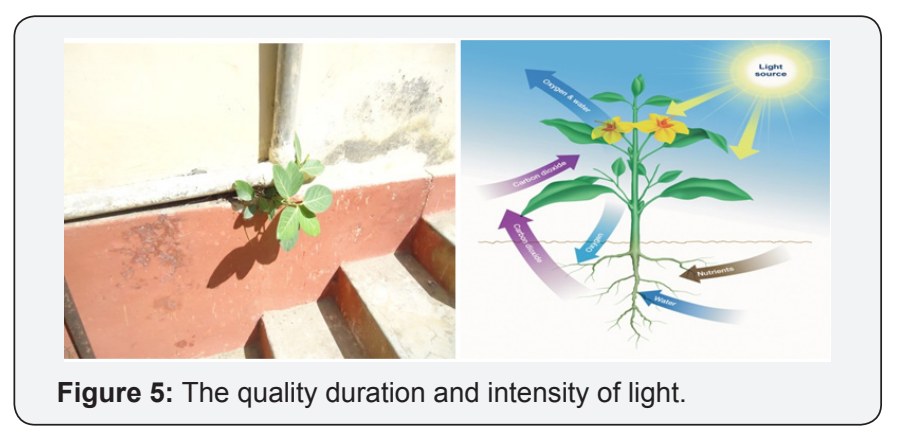




\section{Substrate}

This is one of the key factors for evaluating the adaptability of plant is certain situations. The formation of substrate does not regard only the manner in which the wall is built but also biotic (decomposition by microorganism) and abiotic (climatic agents and atmospheric pollution) factors [5]. These factors contribute to the crumbling of lime mortor, leading to the formation of fissures and cavities within the walls. Substrate rich in detritus can form in these spaces with the auxiliary of atmospheric dust, bird excrement, human wastes, bryophytes, lichens, bacteria and fungi normally present in soil. Moss often creates the environment necessary for the germination of seeds in some cases the relations between tracheophytes and bryophytes are regulated by inhibitory allelophathic mechanisms. In fact substances which inhibit seed germination and root growth of higher plant have been isolated bryophytes. e.g., Lunaric acid from Lunularia Cruciata (L). In other cases the moss gametophyte constituting on absorbent surface, collects dust and other material. The resulting substrate of organic and inorganic residues can host the germination of seeds. Plants surviving in such environments often have reduced vegetative and reproductive parts; since the mural habitat does not permit them to develop to normal size. Places facilitating the rooting of plants of this type may be protruding shelves or irregular surfaces which provide space for the build-up detritus or soil [6]. The amount of substrate needed for Seed germination varies from specie to species. Shrub and tree (chamaephytes, phanerophytes) require more substrate and therefore prefer to grow along earth- fill walls offering a substantial amount of soil (Figure 6).

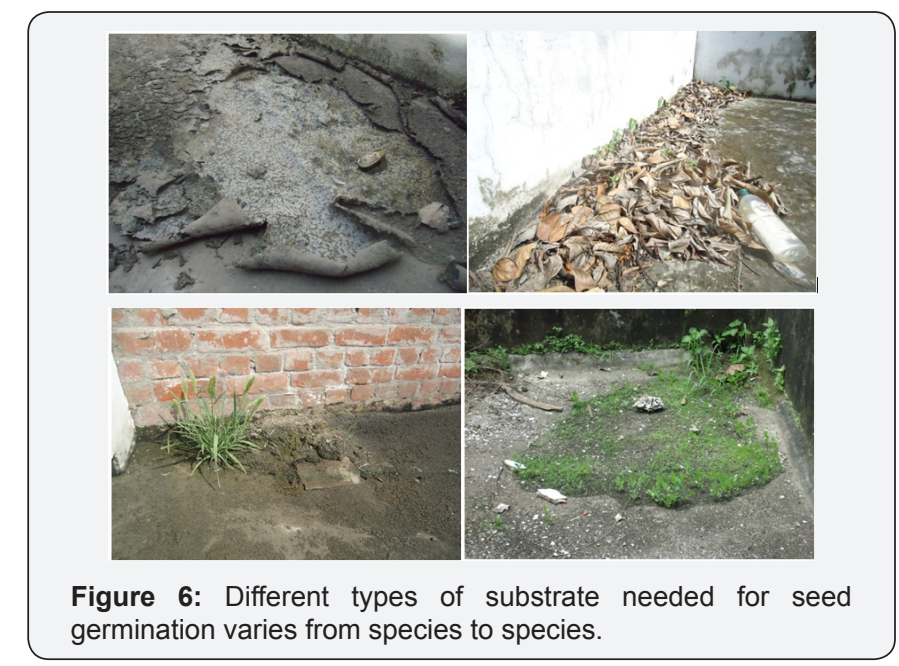

\section{Nutrients}

The availability and type of nutrients present in the substrate also play an important role in the growth of plant. Nutrients can be either organic or inorganic in nature [7]. The organic nutrients may be either an impurity in the substrate or decomposition product of other microorganism. The inorganic nutrients are usually the mineral constituents of the substrates (Figure 7).
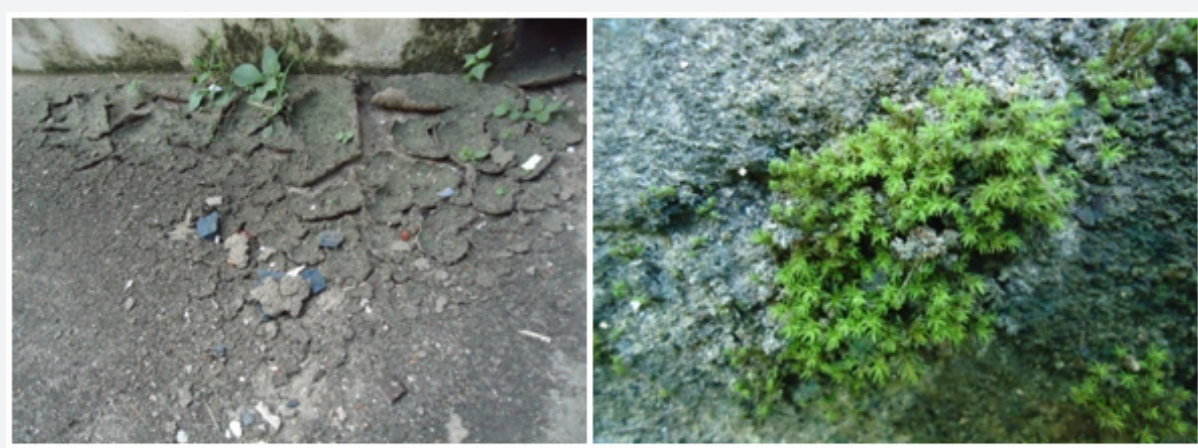

\begin{tabular}{|c|c|c|c|}
\hline \multicolumn{4}{|c|}{ Essential Plant Nutrients } \\
\hline \multirow{2}{*}{ Mineral } & \multicolumn{3}{|c|}{ Non-Mineral } \\
\cline { 2 - 4 } & \multicolumn{2}{|c|}{ Macronutrients } & Micronutrients \\
\cline { 2 - 3 } & Primary & Secondary & \\
\hline Hydrogen & Nitrogen & Calcium & Boron \\
\hline Oxygen & Phosphorus & Magnesium & Copper \\
\hline Carbon & Potassium & Sulfur & Iron \\
& & & Chloride \\
& & & Manganese \\
& & & Molybdenum \\
& & & Zinc \\
\hline
\end{tabular}

Figure 7: Essential Plants Nutrients. 


\section{Bird's Excretion}

Seeds of murophytes like Ficus species migrate their primary sources (mother trees) in the nearby vicinity to the buildings via by biological victors (birds and mammals), their role was confirmed in dispersal of plants seeds through scatological studied. Birds and animals occupy these places for shelter, nesting, feeding, wintering, roosting etc. They enjoy eating plants fruits and consequently disperse seeds through their scat and droppings. Many animals dispose off their dropping on walls of the buildings. The rain washes the droppings and seeds are further dispersed. The plants seed are light in weight, hence easily shifted by flow of runoff and occupy appropriate germination sites (Figure 8).

\section{Building Structure}

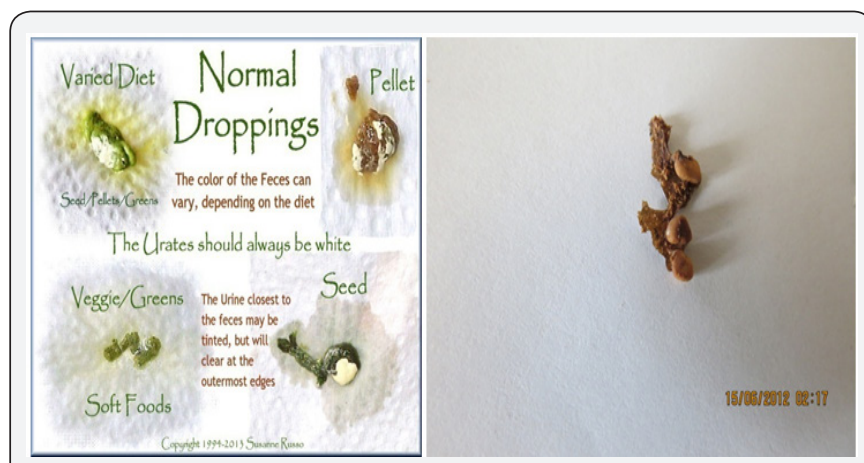

Figure 8: The types of bird's fecal matter and showing plants seed in bat (Pteropusgianteus) excreta.

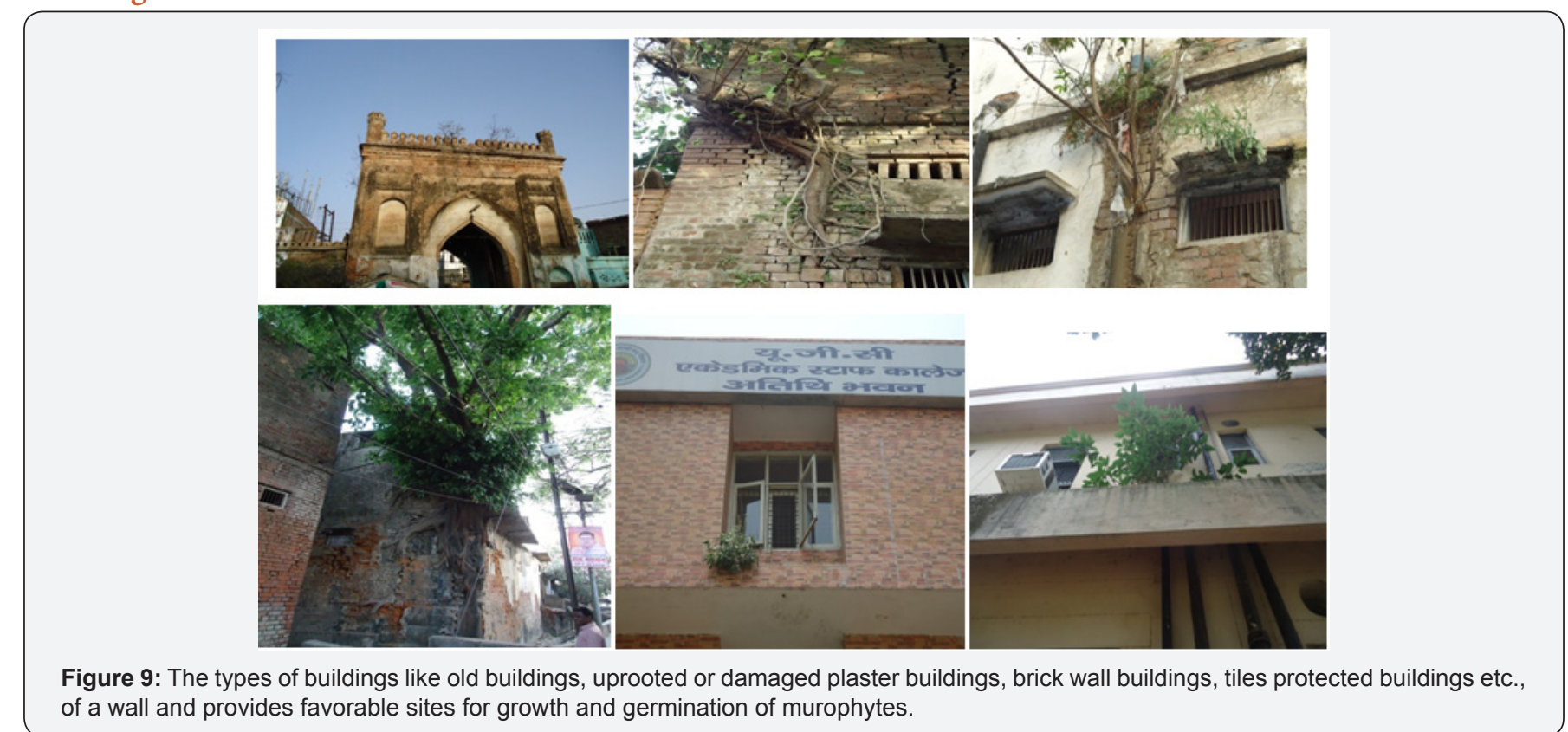

The architecture of old buildings and the magnificent carvings for beautification provides more anchoring points for the settlement of seeds. Horizontal and vertical folds and joints in the carvings act as a capillary and facilitate the seed to settle with the movement of water [8]. The uprooted or damaged plaster of a wall provides favorable sites for germination of murophytes [9]. Walls have many primary seed traps, where the seeds are initially captured in building. After the growth of the plants, walls are further damaged and they provide secondary and tertiary seeds traps too. This will result in the successive damage of buildings and make them more vulnerable [10] (Figure 9).

\section{Conclusion}

These predominating factors which are involved in the deterioration have occurred not only because of the age of the structure but also mostly due to the environmental conditions and factors. Climate can be defined as the certain atmospheric events such as rainfall, temperature, wind, pressure and humidity that cause certain damages on the bridge, house, concrete buildings, monumental buildings etc., in the course of time.

The most important factor related to the deterioration encountered on the monumental and building structure and to growth and development of murophytes is the "humidity" factor. In general water and moisture act on structures as "rising from soil", "condensing" and "rainwater".

\section{References}

1. Ruby J, Nathan PT, Balasingh J, Kunz TH (2000) Chemical composition of Fruits and leaves eaten by short nosed fruit bat Cynopterus sphinx. J Chem Ecol 26(12): 2825-2841.

2. Slocum MG, Horvitz CC (2000) Seed arrival under different genera of trees in neotropical pasture. Plant Ecology 149(1): 51-62.

3. Godgil M, Vartak V D (1974) The scared groves of western ghats in India. Econ Bot 30: 152-162.

4. Godgil M (1987) Social restraint on exploiting nature: The Indian experiences develop. Seed change 1: 26-30. 
5. Dwivedi Anil K, Deependra Kr Anand (2013) The Murophyte, Indian Science Cruiser 27(1): 32-35.

6. Dwivedi Anil K, Dipendra Kr Anand (2014) Investigation of Diversity in Murophytes in the Campus of University in Gorakhpur, India, International J Plant Animal and EnvScis 4(3): 569-575.

7. Roccardi A, Bianchette PL (1988) The distribution of lichens on some stone works in the surrounding of Rome, Studia Geobotanica 8: 89-97.
8. Lisci M, Pacini E (1993) Plants growing on the walls of Italian town site and distribution, Phyton (Horn, Austria) 33(1): 15-26.

9. King G (1887) Observations on the genusFicus with special reference to the Indo Malayan and Chinese species. J Linn Soc Bot 24: 27-44.

10. Dwivedi Anil K, Dipendra Kr Anand (2014) Ficus is the Most Dominent Murophyte. J Env Bio-Sci 28(1): 9-12.
This work is licensed under Creative Commons Attribution 4.0 Licens
Your next submission with Juniper Publishers will reach you the below assets

- Quality Editorial service

- Swift Peer Review

- Reprints availability

- E-prints Service

- Manuscript Podcast for convenient understanding

- Global attainment for your research

- Manuscript accessibility in different formats

( Pdf, E-pub, Full Text, Audio)

- Unceasing customer service

Track the below URL for one-step submission https://juniperpublishers.com/online-submission.php 